\title{
FUTURE TEACHER TRAINING FOR THE USE OF AUGMENTED REALITY IN THE EDUCATIONAL PROCESS OF A PRESCHOOL EDUCATION INSTITUTION
}

\section{ПІДГОТОВКА МАЙБУТНІХ ПЕДАГОГІВ ДО ВИКОРИСТАННЯ ДОПОВНЕНОЇ РЕАЛЬНОСТІ В ОСВІТНЬОМУ ПРОЦЕСІ ЗАКЛАДУ ДОШКІЛЬНОї ОСВІТИ}

\author{
Liudmyla Kozak ${ }^{1}$ \\ Tatyana Ponomarenko ${ }^{2}$
}

DOI: https://doi.org/10.30525/978-9934-26-077-3-12

Abstract. The article substantiates the importance of future teacher training for the use of augmented reality (AR) in the educational process of a preschool education institution (PEI). Scientific sources on the problem of AR application in the field of education are analysed. The aspects of the research of the problem of AR application are defined in the field of education done by modern foreign and national scientists, in particular, the use of AR applications in education; introduction of 3D technologies, virtual reality (VR) and augmented reality in the educational process of preschool and primary school; application of $3 \mathrm{~d}$ technology, virtual and augmented reality in a higher education institution; increasing the efficiency of training and motivation of students on the basis of using AR applications in smartphones; the formation of reading culture by means of augmented reality technology; prospects for the use of augmented reality within the linguistic and literary field of preschool and primary education. The specifics of publications of fiction works with AR applications are analysed that are appropriate to use in work with preschool children; the possibilities of books for preschool children created with the help of

\footnotetext{
${ }^{1}$ Doctor of Pedagogical Sciences, Associate Professor, Professor at the Chair of Preschool Education,

Pedagogical Institute, Borys Grinchenko Kyiv University, Ukraine

${ }^{2}$ Doctor of Pedagogical Sciences, Professor,

Professor at the Chair of Preschool Education, Ukraine

Pedagogical Institute, Borys Grinchenko Kyiv University, Ukraine

(C) Liudmyla Kozak, Tatyana Ponomarenko
} 
augmented reality technology are demonstrated. The possibilities of using AR in work with preschoolers are considered. The urgency of the use of AR for the effective education and development of preschoolers is determined. The problems of application of AR in the educational process of modern national PEI are outlined. A method of diagnostic research of the level and features of readiness of future teachers to use AR in the educational process of PEI has been developed. Criteria and indicators are defined, the levels of development of the main components of the studied readiness (cognitive and active) and the indicated readiness as a whole are characterized. The following points are proved: insufficiency and deficit of its formation of future teachers of the field of preschool education; inconsistency between the peculiarities of future teacher training to use AR in professional activities and modern requirements for the quality of educational process in PEI; the need to develop and implement a model for the formation of the studied readiness of future teachers of the institution of higher pedagogical education. A step-by-step model of formation of readiness of future teachers to use $\mathrm{AR}$ in the educational process of PEI has been developed.

\section{1. Вступ}

У сучасному суспільстві розвиток цифрових технологій дає можливість модернізувати освітній процес. Використання цифрових технологій в галузі освіти дозволяє прискорити передачу досвіду, підвищити якість освітньої діяльності. Однією з ефективних інноваційних технологій є технологія доповненої реальності (AR) - доповнення фізичного світу за допомогою цифрових даних в режимі реального часу; технологія накладання віртуальної реальності на об'єкти фізичного світу. Використання такої технології в освітньому процесі закладу дошкільної освіти підвищує рівень засвоєння досвіду за рахунок інтерактивності іiі представлення у форматі 3D, дає можливість педагогу швидко та доступно пояснити складний для уяви дитини матеріал, а дітям легко його засвоїти, сприяє розвитку креативності, підвищує пізнавальну активність дітей, допомагає довше утримувати їхню увагу, адже доповнена реальність викликає в дітей захоплення й відчуття чогось надзвичайного.

В Україні розроблено й затверджено нову редакцію Базового компоненту дошкільної освіти (БКДО) [1]. В означеному доку- 
менті вимоги до обов'язкових освітніх результатів, компетентностей дошкільників визначено за освітніми напрямами інваріантного складника («Особистість дитини», «Дитина в сенсорно-пізнавальному просторі», «Дитина в природному довкіллі», «Гра дитини», «Дитина в соціумі», «Мовлення дитини», «Дитина в світі мистецтва») й складника варіативного («Особистість дитини. Спортивні ігри», «Дитина в сенсорно-пізнавальному просторі. Комп'ютерна грамота», «Мовлення дитини. Основи грамоти», «Мовлення дитини. Іноземна мова», «Дитина в соціумі. Соціально-фінансова грамотність», «Дитина у світі мистецтва. Хореографія» тощо).

Результати аналізу наукових джерел та практичного досвіду в галузі дошкільної освіти свідчать, що технологію доповненої реальності доцільно використовувати 3 метою ефективного формування будь-якої 3 компетентностей дошкільників (рухової й здоров'язбережувальної, особистісної, предметно-практичної й технологічної; сенсорно-пізнавальної, логіко-математичної й дослідницької; природничо-екологічної; ігрової; соціально-громадянської; мовленнєвої, художньо-мовленнєвої, мистецько-творчої тощо), визначених у межах вищеозначених напрямів, та в різних видах діяльності дошкільників: руховій, ігровій, мистецько-творчій, пізнавально-дослідницькій, господарчо-побутовій тощо.

Також використання в освітньому процесі закладу дошкільної освіти технології AR здатне впливати на ефективність формування умінь, навичок, що є спільними для дошкільної та початкової освіти (проявляти творчість та ініціативність; керувати емоціями; висловлювати та обгрунтовувати власну думку; критично мислити; приймати рішення; розв'язувати проблеми; співпрацювати в колективі тощо) й сприяти наступності між дошкільною та початковою освітою.

Водночас на підставі аналізу сучасного стану вітчизняної дошкільної освіти можна зробити невтішні висновки стосовно дефіциту в багатьох педагогів досвіду використання технології доповненої реальності в освітньому процесі закладу дошкільної освіти. Оскільки використання AR-технології не передбачається програмами виховання й розвитку дошкільників, а навчальні посібники для майбутніх і чинних педагогів не містять завдань, пропозицій, які фахівцям необхідно реалізовувати в освітній галузі, то володіння новою технологією, в кращому випадку, здебільшого здійснюється педагогами в самостійній діяльності й засто- 
совується не системно й хаотично. Крім того, існують психологічні бар'єри в застосовуванні педагогами нових технологій. Багато 3 них продовжують працювати в звичному неінноваційному режимі.

Вищеозначене має особливу значущість для вищої педагогічної освіти, оскільки існує нагальна потреба формування в майбутніх педагогів здатності до використання доповненої реальності в освітньому процесі закладу дошкільної освіти 3 метою іiї успішної актуалізації в подальшій професійній діяльності.

Проте спостерігається неузгодженість між підготовкою фахівців для вітчизняної дошкільної освіти, що здійснюється в умовах університетської педагогічної освіти, й потребами практики освіти дітей дошкільного віку. Отже, набула гостроти проблема забезпечення процесу формування готовності майбутніх педагогів в умовах закладу вищої освіти до використання технології AR у практиці дошкільної освіти.

Мета статті полягає у висвітленні результатів дослідження стану готовності майбутніх педагогів до використання технології доповненої реальності в освітньому процесі закладу дошкільної освіти й розробки поетапної моделі іiі формування в умовах університетського навчання.

У контексті означеної мети визначено такі завдання дослідження:

- обгрунтувати актуальність підготовки майбутніх педагогів до використання технології доповненої реальності в освітньому процесі закладу дошкільної освіти;

- визначити актуальність застосування технології доповненої реальності для ефективного виховання й розвитку дітей дошкільного віку;

- проаналізовати наукові джерела з проблеми застосування доповненої реальності в освітній галузі;

- окреслити проблеми при застосуванні технології доповненої реальності в освітньому процесі сучасних вітчизняних закладів дошкільної освіти;

- розглянути можливості використання технології доповненої реальності в роботі з дітьми дошкільного віку;

- проаналізовати специфіку художніх творів з AR-додатками, які доречно застосовувати в роботі з дітьми дошкільного віку;

- продемонстровати можливості книжок, розвивальних ігор для дітей дошкільного віку, створених за допомогою технології доповненої реальності; 
- дослідити сучасний стан готовності майбутніх педагогів до використання технології доповненої реальності в професійній освітній діяльності;

- розробити поетапну модель формування готовності майбутніх педагогів до використання AR в освітньому процесі закладу дошкільної освіти.

\section{2. Дослідження проблеми застосування} доповненої реальності в галузі освіти

У контексті дослідження нами проаналізовано ряд наукових робіт, які зосереджені на вивченні застосування технології доповненої реальності в широкому діапазоні освітнього контексту та надають відповідне розуміння того, як використання технології AR зумовлює якість освіти студентів, учнів і дітей дошкільного віку в умовах освітніх закладів.

Доповнена реальність (Augmented Reality, скорочено - AR) - технологія інтерактивної комп’ютерної візуалізації, що дає змогу доповнити зображення реального світу віртуальними елементами й відображає його на екрані пристрою. Це дозволяє користувачам бачити реальний світ одночасно з віртуальними зображеннями, прикріпленими до реальних місць та об'єктів [5].

Доведено (Mehmet Kesim, Yasin Ozarslan) [8], що застосування технології доповненої реальності для засвоєння змісту певного досвіду підвищує ефективність, привабливість освітньої діяльності, оскільки покращує сприйняття студентами реального довкілля та взаємодію 3 ним. За допомогою систем доповненої реальності студенти взаємодіють із 3D-інформацією, предметами, процесами, подіями. Вони можуть переміщатися по тривимірному віртуальному зображенню й переглядати його з будь-якої точки зору, як і реальний об'єкт. Інформація, яку передають віртуальні об'єкти, допомагає студентам виконувати практичні завдання.

Dutta Kamalika [7] вважає, що практичний та візуальний аспекти навчання дозволяють пришвидшити розуміння змісту матеріалу, оскільки зорова пам'ять ефективно стимулюється. Дослідження показали, що використання доповненої реальності значно збільшує обсяг інформації, яку запам'ятовують студенти, й крім того, ця інформація зберігається в їх довготривалій пам'яті. 
Досліджуючи використання технології доповненої реальності в мобільному навчальному середовищі закладу вищої освіти, Є. Модло, Ю. Счкало, С. Семеріков, В. Ткачук [3; 4] констатують, що застосування означеної технології надає можливість підвищити реалістичність дослідження; забезпечує емоційний та пізнавальний досвід, що сприяє залученню студентів до систематичного навчання; створює нові способи подання реальних об'єктів у процесі освітньої діяльності; мотивує студентів до експериментальної та навчально-дослідницької роботи.

На засадах дослідження дидактичного потенціалу віртуального інформаційного навчання О. Bondarenko, O. Pakhomova, W. Lewoniewski [6] визначають такі особливості технологій віртуальної й доповненої реальностей як занурення, динамічність, почуття присутності, наступність, причинність, інтенсифікація процесу пізнання, економії часу при опрацюванні матеріалу. Підтверджуючи ефективність навчання за допомогою VR та AR технологій, автори вказують й на певні проблеми в їх використанні, зокрема, низький рівень комп'ютерізації освітнього процесу, незначна кількість та низька якість програмних продуктів тощо.

Важливим $є$ положення про те, що справжнє навчання $є$ експериментальним. Чим більше органів чуття задіяно в освітньому процесі (слуховий, зоровий, тактильний тощо), тим ефективнішими будуть результати освіти. В такому контексті доповнена реальність має велике значення для підтримки експериментального навчання й забезпечує тим, хто навчається, привабливий технологічний інструмент для забезпечення їх успішної навчальної діяльності. Дослідниками розроблено додаток AR, який поєднує в собі 3D-моделі й анімацію, міні-ігри та вікторини. Розробниками було обрано навчальний предмет для початкової школи «Знання природного, соціального та культурного навколишнього середовища». Розроблена система доповненої реальності «Realitat 3» складається з механізму AR та шести додатків: скелетний апарат, кругообіг води, розвиток рослин, метаморфоза жаб, Сонячна система, органи чуття [12].

Особливої уваги заслуговує розроблений мобільний додаток для програми початкової школи 3 метою отримання дітьми нового рівня досвіду в галузі загальнонаукових концепцій, таких як вивчення матеріалів, твердих тіл, рідин, газів, різних явищ, Всесвіту та галактик, основних частин скелета людини, травної й дихальної системи тощо [11]. 
Актуальним $є$ дослідження перспектив використання доповненої реальності в межах мовно-літературної галузі початкової освіти (L. Nezhyva, S. Palamar, O. Lytvyn) [10]. Дослідники відзначають, що візуалізація художнього образу засобами доповненої реальності сприяє ефективності навчання в різних напрямах, зокрема: створює WOW-ефект, дивує, чим поглиблює емоційний резонанс від читання художнього твору; стає потужною мотивацією до читацької діяльності; сприяє розвитку творчої уяви; забезпечує сприйняття художнього образу різними органами чуття; демонструє дітям користь гаджетів для навчання й особистісного розвитку.

У дошкільній освіті також існує можливість застосовувати технології доповненої реальності. До таких продуктів належать ігри-подорожі, книги-розмальовки, інтерактивні абетки, енциклопедії й художні книжки.

Отже, більшість публікацій з визначеної проблеми свідчить про можливість використання VR та AR технологій в освітній галузі 3 метою візуального моделювання навчального матеріалу, доповнення його наочністю, забезпечення в дітей емоційного та пізнавального досвіду, навичок дослідження й експериментування, що прискорює набування певного досвід й робить цей процес цікавим і діяльнісним.

\section{3. Застосування доповненої реальності у вихованні й розвитку дошкільників}

Результати аналізу сутності технології AR та змісту компетентностей, які необхідно сформувати в дітей дошкільного віку за Базовим компонентом дошкільної освіти (Державним стандартом дошкільної освіти) [1], дозволяють констатувати, що використання в освітньому процесі закладу дошкільної освіти технології доповненої реальності здатне сприяти ефективному формуванню означених компетентностей.

Так, використання в освітньому процесі книг $з$ доповненою реальністю (казки Ганса Крістіана Андерсена «Дикі лебеді» (2019 р.), «Снігова королева» (2019 р.); Шарля Перро «Спляча красуня» (2019 р.), «Кіт у чоботях» (2020р.) тощо) зумовлює можливість формування в дітей старшого дошкільного віку різних компонентів соціально-громадянської компетентності (інтересу до загальнолюдських цінностей, цінностей спілкування; знань про значення, сутність, конкретні про- 
яви особистісних якостей (самостійності, відповідальності, працелюбності, лідерства, ініціативності, активності, креативності тощо) у стосунках з іншими людьми; усвідомлення соціальних правил та норм поведінки у щоденній життєдіяльності тощо).

Застосування в роботі з дітьми молодшого дошкільного віку книги 3 доповненою реальністю «Колобок» сприяє формуванню певних компонентів сенсорно-пізнавальної, логіко-математичної компетентностей - готовності до спрямування сенсорних процесів (відчуття, сприйняття, уваги тощо) на пізнання об'єктів довкілля; формування уявлень про основні математичні поняття «число», «величина», «форма», «простір», «час», «колір» тощо.

За допомогою книги «Кобзарева абетка» (2019 р.), яка містить твори Тараса Шевченка на кожну букву алфавіту, ілюстрації до яких оживають, рухаються й розмовляють за допомогою безкоштовного додатку FastAR Kids у смартфонах або планшетах (iOS, Android, iPhone), можна формувати в дошкільників такі компоненти мовленнєвої компетентності як розуміння того, що в Україні українська мова $\epsilon$ державною; усвідомлення звукового складу рідної мови, спираючись на розвинений фонематичний слух і мовленнєве дихання; виховувати любов до рідної мови, повагу до державної мови, мов представників національних меншин України тощо.

Використання доповненої реальності також спрямоване на формування в дошкільників цифрової компетентності - формування уявлень про інформаційно-комунікаційні та цифрові технології як сучасні технічні засоби, що розширюють інформаційні обрії та допомагають орієнтуватися в довкіллі в умовах високої технізації життя; формування здатності до використання інформаційно-комунікаційних та цифрових технологій для задоволення власних індивідуальних потреб і розв'язання освітніх, ігрових завдань на основі набутих елементарних знань, умінь, позитивного ставлення, інтересу до комп'ютерної та цифрової техніки (телефон, комп’ютер, планшет) тощо.

Разом з тим результати аналізу теорії й практики дошкільної освіти свідчать про наявність цілої низки проблем у застосуванні доповненої реальності в освітньому процесі сучасних вітчизняних закладів дошкільної освіти. Так, незважаючи на те, що дошкільники в сучасному соціумі звикають до різноманітних гаджетів (смартфонів, 
планшетів тощо), які поступово перетворюються в один із важливих засобів пізнання довкілля, більшість не мають навичок оперування гаджетами в побутових умовах та в умовах освітнього процесу. Спостерігається дефіцит мобільних AR-додатків для візуалізації досвіду, який необхідно засвоїти дітям на етапі дошкільного дитинства. Використання дошкільниками гаджетів цілком правомірно обмежується цілою низкою санітарно-гігієнічніх обмежень, на засадах урахування особливостей фізичного, психологічного, емоційного розвитку дітей дошкільного віку.

\section{4. Дослідження готовності майбутніх педагогів} до використання технології AR в професійній діяльності

3 метою перевірки отриманих в ході теоретичного дослідження результатів проведено емпіричне дослідження. В дослідженні брала участь група студентів-магістрантів спеціальності «Дошкільна освіта» (денна й заочна форми навчання; всього - 87 осіб).

В якості методів дослідження використовувалося анкетування та виконання діагностичного завдання. Зміст питань анкети, завдання визначався на основі вивчення та аналізу теорії й практики застосування доповненої реальності в освітній галузі.

Зміст питань анкети для студентів-магістрантів був таким: 1) «У чому, на Ваш погляд, полягає сутність поняття «здатність педагогів до використання доповненої реальності в освітньому процесі закладу дошкільної освіти»?; 2) «Наскільки ефективним Ви вважаєте освітній процес щодо формування здатності майбутніх педагогів до використання доповненої реальності в освітньому процесі закладу дошкільної освіти?».

Зміст діагностичного завдання було визначено таким чином. «Розробити конспект інтегративного заняття для дітей старшого дошкільного віку з будь-якого освітнього напряму Базового компоненту дошкільної освіти («Дитина в сенсорно-пізнавальному просторі», «Дитина в природному довкіллі», «Дитина в соціумі», «Мовлення дитини» тощо) із застосовуванням технології доповненої реальності 3 метою візуального моделювання навчального матеріалу, доповнення його наочністю. Визначити й обгрунтувати доцільність застосовування технології доповненої реальності. Створити модель використання AR. 
Визначити мобільні додатки для візуалізації навчального матеріалу й гаджети, якими доцільно оперувати. Реалізувати конспект в освітній практиці закладу дошкільної освіти».

Розробка конспекту інтегративного заняття здійснювалася протягом академічної години (1 год. 20 хвилин). Перед початком виконання завдання респондентам пояснювали, що вони будуть робити. Намагалися викликати інтерес до запропонованої діяльності, створити мотивацію для iï виконання. Зміст конспекту реалізовувався студентами в період виробничої педагогічної практики в умовах закладу дошкільної освіти.

Сутність основного поняття дослідження «готовність педагогів до використання доповненої реальності в освітньому процесі закладу дошкільної освіти» ми визначили як цілісну, інтегративну, досить складну за змістом якість особистості, що являє собою сукупність ціннісних орієнтацій, мотивів, знань, умінь, навичок, особистісно-професійних якостей, які зумовлюють ефективність застосування доповненої реальності.

Ми також брали до уваги, що доповнена реальність (англ. augmented reality, AR) - це термін, який позначає всі проєкти, спрямовані на доповнення реальності будь-якими віртуальними елементами; це результат введення в поле сприйняття будь-яких сенсорних даних 3 метою доповнення відомостей про оточення й поліпшення сприйняття інформації [2].

Узагальнення сутності вищеозначеного поняття дає можливість констатувати, що в процесі застосування AR здійснюється використання довкілля та поверх нього накладається певна частинка віртуальної інформації, наприклад, графіка, звуки тощо. Оскільки віртуальне та реальне довкілля гармонійно співіснують, користувачі 3 досвідом застосування доповненої реальності мають змогу спробувати відчути, побачити, сприйняти дещо нове, більш наочне, чітке, яскраве оточення, де віртуальна інформація використовується як додатковий корисний інструмент пізнання довкілля, набування більш усвідомленого, узагальненого, диференційованого, глибокого досвіду.

На засадах аналізу наукової літератури $з$ метою виявлення рівня розвитку готовності майбутніх педагогів закладів дошкільної освіти до використання доповненої реальності було визначено основні критерії, що розкриваються через визначені нами показники. 
Когнітивний критерій 3 показником: знання змісту поняття «готовність педагогів до використання доповненої реальності в освітньому процесі закладу дошкільної освіти».

Діяльнісний критерій з показниками: розробка конспекту інтегративного заняття для дітей дошкільного віку з будь-якого освітнього напряму Базового компоненту дошкільної освіти із застосовуванням технології доповненої реальності; визначення й обгрунтування доцільності застосовування технології доповненої реальності; розробка моделі застосування AR; визначення мобільних додатків для візуалізації навчального матеріалу; визначення гаджетів, якими доцільно оперувати; реалізація конспекту в освітній практиці закладу дошкільної освіти.

За результатами аналізу відповідей на перше питання анкети студентів-магістрантів було поділено на три групи відповідно рівням розвитку їх когнітивного компоненту готовності до використання доповненої реальності в освітньому процесі закладу дошкільної освіти.

Достатній рівень розвитку когнітивного компоненту готовності педагогів до використання доповненої реальності в освітньому процесі закладу дошкільної освіти виявлено в студентів, які в змісті досліджуваного поняття визначають: основні компоненти готовності до використання доповненої реальності в освітньому процесі закладу дошкільної освіти (знання, уміння навички); сутність поняття «доповнена реальність» як процесу («доповнення реальності будь-якими віртуальними елементами»; «використання довкілля, поверх якого накладається певна частина віртуальної інформації»; «введення в поле сприйняття будь-яких сенсорних даних» тощо); мету використання доповненої реальності в галузі дошкільної освіти.

До не зовсім достатнього рівня розвитку когнітивного компоненту готовності педагогів до використання доповненої реальності в освітньому процесі ЗДО віднесено студентів, які в змісті досліджуваного поняття визначають не достовірно або зовсім не називають один або декілька із основних компонентів готовності педагогів до використання доповненої реальності в освітньому процесі ЗДО (основні компоненти здатності до використання доповненої реальності (знання, уміння навички); сутність поняття «доповнена реальність» як процесу; мета використання AR у галузі дошкільної освіти). 
До недостатнього рівня розвитку когнітивного компоненту готовності педагогів до використання доповненої реальності в освітньому процесі ЗДО віднесено студентів, які в змісті досліджуваного поняття не визначають: жоден із основних компонентів здатності педагога до використання доповненої реальності в освітньому процесі ЗДО (основні компоненти здатності до використання доповненої реальності (знання, уміння навички); сутність поняття «доповнена реальність» як процесу; мета використання AR у галузі дошкільної освіти); а також студентів, у відповідях яких сутність поняття звужується до узагальнень, що не відповідають науковому визначенню досліджуваного поняття (наприклад, «застосування гаджетів» тощо).

Кількісне співвідношення рівнів розвитку когнітивного компоненту готовності до використання доповненої реальності в освітньому процесі закладу дошкільної освіти в студентів закладу вищої педагогічної освіти представлено в таблиці 1.

Таблиця 1

Кількісне співвідношення рівнів розвитку когнітивного компоненту готовності студентів до використання доповненої реальності в освітньому процесі закладу дошкільної освіти

Рівні розвитку когнітивного компоненту готовності студентів до використання доповненої реальності в освітньому процесі закладу дошкільної освіти

\begin{tabular}{|c|c|c|}
\hline достатній & не зовсім достатній & недостатній \\
\hline $8(8,7 \%)$ & $27(29,3 \%)$ & $57(62 \%)$ \\
\hline
\end{tabular}

Таким чином, аналіз результатів проведеного дослідження дозволяє засвідчити наступне. У 8 (8,7\%) студентів було виявлено достатній рівень розвитку когнітивного компоненту здатності до використання доповненої реальності в освітньому процесі закладу дошкільної освіти. В 27 (29,3\%) респондентів виявлено не зовсім достатній рівень розвитку означеного компоненту. У 57 (62\%) респондентів виявлено не достатній рівень розвитку когнітивного компоненту здатності педагогів до використання доповненої реальності в освітньому процесі закладу дошкільної освіти.

Кількісне співвідношення відповідей студентів на друге питання анкети «Наскільки ефективним Ви вважаєте освітній процес щодо фор- 
мування готовності майбутніх педагогів до використання AR в освітньому процесі закладу дошкільної освіти?» представлено в таблиці 2.

Таблиця 2

\section{Кількісне співвідношення відповідей студентів} на друге питання анкети

\begin{tabular}{|c|c|c|}
\hline \multicolumn{3}{|c|}{$\begin{array}{c}\text { Кількість відповідей студентів, у яких освітній процес у 3BO } \\
\text { щодо формування готовності майбутніх педагогів до використання AR } \\
\text { в освітньому процесі ЗдО визначаєтья як }\end{array}$} \\
\hline \multirow{2}{*}{ ефективний } & $\begin{array}{c}\text { недостатньо } \\
\text { ефективний }\end{array}$ & не ефективний \\
\hline $11(12 \%)$ & $23(25 \%)$ & $58(63 \%)$ \\
\hline
\end{tabular}

Аналіз відповідей на друге питання анкети дозволяє констатувати, що 11 (12\%) респондентів вважають освітній процес 3 метою формування здатності майбутніх педагогів до використання доповненої реальності в освітньому процесі закладу дошкільної освіти ефективним; 23 (25\%) респондентів - недостатньо ефективним; 58 (63\%) респондентів - неефективним.

За результатами аналізу вирішення діагностичного завдання студентів було поділено на три групи відповідно рівням розвитку їх діяльнісного компоненту готовності до використання доповненої реальності в освітньому процесі закладу дошкільної освіти.

Так, достатній рівень розвитку діяльнісного компоненту готовності до використання AR в освітньому процесі ЗДО виявлено в студентів, які методично правильно розробили конспект інтегративного заняття для дошкільників 3 будь-якого освітнього напряму БКДО із застосовуванням AR; визначили й обгрунтували доцільність застосовування технології AR; створили модель застосування AR; визначили мобільні додатки для візуалізації навчального матеріалу й гаджети, якими доцільно оперувати; методично доцільно реалізували розроблений конспект в освітній практиці ЗДО.

Не зовсім достатній рівень розвитку діяльнісного компоненту готовності до використання доповненої реальності в освітньому процесі ЗДО виявлено в студентів:

- які при розробці конспекту інтегративного заняття для дітей дошкільного віку з будь-якого освітнього напряму БКДО із застосову- 
ванням технології доповненої реальності допускали певні методичні помилки; не досить переконливо визначали й обгрунтовували доцільність застосовування технології AR; допускали помилки при розробці моделі застосування AR, визначенні мобільних додатків для візуалізації навчального матеріалу й гаджетів, якими доцільно оперувати; мали певні утруднення в процесі реалізації конспекту в освітній практиці закладу дошкільної освіти.

- які методично правильно розробили конспект інтегративного заняття для дітей дошкільного віку з будь-якого освітнього напряму БКДО із застосовуванням технології доповненої реальності; визначили й обгрунтували доцільність застосовування технології AR; створили модель застосування AR; визначили мобільні додатки для візуалізації навчального матеріалу й гаджети, якими доцільно оперувати; проте не змогли реалізувати інтегративне заняття для дітей дошкільного віку 3 будь-якого освітнього напряму БКДО із застосовуванням технології доповненої реальності в освітньому процесі закладу дошкільної освіти.

Недостатній рівень розвитку діяльнісного компоненту готовності до використання доповненої реальності в освітньому процесі ЗДО властивий студентам, які не змогли методично правильно розробити конспект інтегративного заняття для дітей дошкільного віку з будь-якого освітнього напряму БКДО із застосовуванням технології доповненої реальності; не здійснили інтегративне заняття для дітей дошкільного віку з будь-якого освітнього напряму БКДО із застосовуванням технології доповненої реальності в освітньому процесі закладу дошкільної освіти.

Кількісне співвідношення рівнів розвитку діяльнісного компоненту готовності до використання AR в освітньому процесі ЗДО в студентів закладу вищої педагогічної освіти представлено в таблиці 3.

Таблиця 3

Кількісне співвідношення рівнів розвитку діяльнісного компоненту готовності студентів до використання AR

в освітньому процесі ЗДО

\begin{tabular}{|c|c|c|}
\hline \multicolumn{3}{|c|}{$\begin{array}{c}\text { Рівні розвитку діяльнісного компоненту готовності студентів } \\
\text { до використання AR в освітньому процесі ЗДО }\end{array}$} \\
\hline достатній & не зовсім достатній & недостатній \\
\hline $7(7,6 \%)$ & $21(22,8 \%)$ & $64(69,6 \%)$ \\
\hline
\end{tabular}


Як видно з таблиці 3, достатній рівень розвитку діяльнісного компоненту досліджуваної якості виявлено в 7 (7,6\%) майбутніх педагогів, не зовсім достатній - у 21 (22,8\%) студента; недостатній - у 64 (69,6\%) студентів.

На засадах аналізу результатів проведеного дослідження було визначено рівні розвитку готовності майбутніх педагогів ЗДО до використання доповненої реальності за визначеними критеріями й показниками. Так, достатній рівень розвитку досліджуваної якості було виявлено в студентів, які мали за результатами анкетування й вирішення діагностичного завдання достатній рівень розвитку когнітивного й діяльнісного компонентів здатності до використання доповненої реальності в освітньому процесі ЗДО.

Не зовсім достатній рівень розвитку досліджуваної якості було виявлено в студентів, які мали за результатами анкетування й вирішення діагностичного завдання не зовсім достатній рівень розвитку когнітивного й діяльнісного компонентів здатності до використання доповненої реальності в освітньому процесі ЗДО, а також студенти, в яких було констатовано достатній рівень розвитку когнітивного компоненту, проте рівень розвитку діяльнісного компоненту виявився недостатнім.

Недостатній рівень розвитку досліджуваної якості було виявлено в студентів, які мали за результатами анкетування й вирішення діагностичного завдання недостатній рівень розвитку когнітивного й діяльнісного компонентів здатності до використання доповненої реальності в освітньому процесі закладу дошкільної освіти.

Кількісне співвідношення рівнів розвитку здатності студентів до використання AR в освітньому процесі ЗДО представлено в таблиці 4.

Таблиця 4

Кількісне співвідношення рівнів розвитку готовності студентів до використання доповненої реальності в освітньому процесі ЗДО

\begin{tabular}{|c|c|c|}
\hline \multicolumn{3}{|c|}{$\begin{array}{c}\text { Рівні розвитку готовності студентів до використання } \\
\text { доповненої реальності в освітньому процесі ЗДО }\end{array}$} \\
\hline достатній & не зовсім достатній & недостатній \\
\hline $6(6,5 \%)$ & $18(19,6 \%)$ & $68(73,9 \%)$ \\
\hline
\end{tabular}


Як видно з таблиці, в 6 (6,5\%) майбутніх педагогів було виявлено достатній рівень розвитку здатності до використання доповненої реальності в освітньому процесі ЗДО. Не зовсім достатній рівень розвитку досліджуваної якості було виявлено у 18 (19,6\%) студентів. Недостатній рівень розвитку досліджуваної якості продемонстрували 68 (73,9\%) майбутніх педагогів ЗДО.

Тож результати проведеного діагностичного дослідження свідчать про досить значну кількість майбутніх педагогів ЗДО, в яких виявлено середній та низький рівень розвитку готовності до використання AR в освітньому процесі закладу дошкільної освіти й зумовлюють необхідність формування досліджуваної готовності в умовах університетського навчання.

На засадах результатів аналізу наукових джерела 3 проблеми застосування AR в освітній галузі й результатів діагностичного дослідження рівня й особливостей готовності майбутніх педагогів до використання AR в освітньому процесі ЗДО нами розроблено модель формування готовності майбутніх педагогів до використання доповненої реальності в сукупності таких етапів: вивчення й аналіз наукових джерел з проблеми дослідження; визначення сутності основного поняття дослідження «готовність педагогів до використання доповненої реальності в освітньому процесі закладу дошкільної освіти» в сукупності його компонентів; розробка моделі ідеальної готовності педагогів до використання AR в дошкільній освіті; аналіз навчальних планів та робочих програм навчальних дисциплін ряду вітчизняних педагогічних університетів з метою виявлення дисциплін, що спрямовані на формування досліджуваної готовності; вивчення сучасного стану готовності майбутніх педагогів до використання AR y професійній діяльності; розробка змісту навчальної дисципліни «Основи готовності педагогів до використання AR в освітньому процесі ЗДО» й уведення означеної дисципліни в навчальний план магістрів спеціальності «Дошкільна освіта»; підготовка викладачів до впровадження розробленої програми в освітньому процесі ЗВО; розробка науково-методичного супроводу формування досліджуваної готовності; за узагальненими наслідками експериментальної роботи підготовка науково-методичних рекомендацій, навчально-методичних посібників тощо. 


\section{5. Висновки}

В умовах інформатизації суспільства, комп'ютеризації та впровадження в освітній процес закладів освіти сучасних інноваційних технологій проблема застосування цифрових технологій стала провідною в педагогічній теорії та практичній діяльності освітніх закладів України, зокрема закладів вищої й дошкільної освіти. Тож в проведеному дослідженні обгрунтовано актуальність підготовки майбутніх педагогів до використання технології AR в освітньому процесі ЗДО. Визначено важливість застосування технології AR для ефективного виховання й розвитку дошкільників. Проаналізовано наукові джерела 3 проблеми застосування доповненої реальності в освітній галузі. Результати аналізу джерел засвідчили необхідність і можливість використання VR та $\mathrm{AR}$ технологій в освітній галузі з метою забезпечення якості освіти.

Результати аналізу наукових джерел та практичного досвіду у сфері дошкільної освіти дозволили констатувати, що технологію доповненої реальності доцільно використовувати з метою ефективного формування будь-якої з компетентностей дошкільників в різних видах їх діяльності. Окреслено проблеми у застосуванні AR в освітньому процесі сучасних вітчизняних ЗДО. Розглянуто можливості використання $\mathrm{AR}$ у роботі з дошкільниками. Проаналізовано специфіку видань художніх творів з AR-додатками, які доречно застосовувати в роботі 3 дітьми. Схарактеризовано можливості книжок, розвивальних ігор для дошкільників, створених за допомогою технології AR.

Досліджено сучасний стан готовності майбутніх педагогів до використання AR у професійній освітній діяльності. На етапі констатувального експерименту було використано взаємопов'язані методи: анкетування, діагностичне завдання з метою вивчення стану сформованості готовності майбутніх педагогів до використання AR-технологій у ЗДО; опис фактичної інформації з метою аналітичної інтерпретації та вивчення конкретних фактів і явищ; кількісна обробка результатів дослідження. Зроблено висновок про дефіцит їі сформованості в майбутніх педагогів у галузі дошкільної освіти; неузгодженість між особливостями їх підготовки до використання технології AR у професійній діяльності та сучасними вимогами до якості освітнього процесу в ЗДО; необхідність розробки й реалізації моделі формування досліджуваної готовності в умовах закладу вищої педагогічної освіти. 
Розроблено поетапну модель формування готовності майбутніх педагогів до використання AR в освітньому процесі ЗДО.

Результати аналізу теорії й практики дошкільної освіти засвідчили наявність цілої низки проблем у застосуванні технології доповненої реальності в освітньому процесі сучасних вітчизняних ЗДО. Так, незважаючи на те, що діти дошкільного віку в сучасному соціумі звикають до різноманітних гаджетів (смартфонів, планшетів тощо), які поступово перетворюються в один із важливих засобів пізнання довкілля, більшість не мають навичок оперування гаджетами в побутових умовах та в умовах освітнього процесу закладу дошкільної освіти. Спостерігається дефіцит мобільних AR-додатків для візуалізації досвіду, необхідного для засвоєння дошкільниками.

Аналіз результатів діагностичного дослідження стану готовності майбутніх педагогів до використання AR в освітньому процесі ЗДО й спостереження педагогічної практики в умовах ЗВО дозволяють окреслити такі проблеми: недостатність сформованості досліджуваної готовності в майбутніх педагогів у галузі дошкільної освіти; неузгодженість між особливостями підготовки майбутніх педагогів до використання технології AR у професійній діяльності та сучасними вимогами до якості освітнього процесу в ЗДО; недостатність підготовки викладачів до формування досліджуваної готовності в умовах 3ВО; необхідність розробки й реалізації моделі формування досліджуваної готовності майбутніх педагогів в умовах закладу вищої освіти.

Перспективи подальших досліджень полягають у реалізації наступних етапів розробленої нами моделі формування досліджуваної готовності: розробка змісту навчальної дисципліни «Основи готовності педагогів до використання AR в освітньому процесі ЗДО» й уведення означеної дисципліни в навчальний план магістрантів спеціальності «Дошкільна освіта»; підготовка викладачів до впровадження розробленої програми в освітній процес закладу вищої освіти; розробка науково-методичного супроводу формування досліджуваної готовності; за узагальненими наслідками експериментальної роботи підготовка науково-методичних рекомендацій, навчальних посібників.

3 метою забезпечення ефективності формування досліджуваної готовності майбутніх педагогів до запровадження доповненої реальності в дошкільній освіті планується використання інноваційного 
класу, створеного в Педагогічному інституті Київського університету імені Бориса Грінченка, який спроєктовано як інноваційний освітній центр для підготовки майбутніх педагогів, формування їх інноваційної професійної компетентності, реалізації завдань STEAM-освіти [12]. Інноваційний клас забезпечено комп'ютерами, інтерактивною дошкою, проєктором та мультифункціональним пристроєм - принтером, сканером, копіром, а також цифровими засобами (ноутбуки, планшети, електронний фліпчарт, інтерактивні дошки та проектори, 3D принтери XYZprinting з модулем лазерної гравіровки). Для проведення занять з використанням технологій віртуальної реальності та доповненої реальності інноваційний клас забезпечено певним оснащенням: шоломом, контролерами та сенсорами положення, планшетами, на які можуть бути встановлені необхідні програми для роботи 3 доповненою реальністю.

\section{Список літератури:}

1. Базовий компонент дошкільної освіти в Україні (Державний стандарт дошкільної освіти) нова редакція (2021). Наказ МОН № 33 від 12.01.2021 року. URL: https://osvita.ua/legislation/doshkilna-osvita/79142/

2. Доповнена, віртуальна та інші реальності (2021). URL: https://www.it.ua/knowledge-base/technology-innovation/dopolnennajavirtualnaja-i-prochie-realnosti

3. Модло С., Счкало Ю., Семеріков С., Ткачук В. (2018) Використання технології доповненої реальності у мобільно орієнтованому середовищі навчання ВНЗ. Наукові записки. Серія: Проблеми методики фізико-математичної і технологічної освіти. Випуск 11(I). 2018. URL: https://arxiv.org/pdf/1807.10659

4. Ткачук В., Семеріков С., Счкало Ю., Модло С. (2017) Технологія доповненої реальності у мобільному навчальному середовищі ВН3. URL: http://ds.knu.edu.ua/jspui/bitstream/123456789/791/1/Tkachuk_Semerikov_ Echkalo_Modlo.pdf

5. Billinghurst, M. (2002) Augmented Reality in Education. Seattle WA: New Horizons for Learning - Technology in Education.

6. Bondarenko, O.V., Pakhomova, O.V., Lewoniewski, W. (2020) The didactic potential of virtual information educational environment as a tool of geography students training. In: Kiv, A.E., Shyshkina, M.P. (eds.) Proceedings of the 2nd International Workshop on Augmented Reality in Education (AREdu 2019), Kryvyi Rih, Ukraine, March 22, 2019. CEUR Workshop Proceedings 2547, 13-23. URL: http://ceur-ws.org/Vol 2547/paper01.pdf (accessed 10 Feb 2020).

7. Dutta Kamalika (2015) Augmented Reality for E-Learning. URL: https://www.researchgate.net/publication/304078112_Augmented_Reality_ for_E-Learning - Title from the screen 
8. Mehmet Kesim and Yasin Ozarslan (2012) Augmented reality in education: current technologies and the potential for education / Procedia - Social and Behavioral Sciences 47. 297-302. URL: https://cyberleninka.org/article/n/1234005.pdf

9. Morze Nataliia, Vember Viktoriia, Boiko Mariia, Varchenko-Trotsenko Liliia (2020) Organization of steam lessons in the innovative classroom. Open educational e-environment of modern University, № 8. 2020. DOI: https://doi.org/ 10.28925/2414-0325.2020.8.9

10. Nezhyva Liudmyla, Palamar Svitlana, Lytvyn Oksana (2020) Perspectives on the use of augmented reality within the linguistic and literary field of primary education. Proceedings of the 3rd International Workshop on Augmented Reality in Education (2731). P. 297-311. ISSN 1613-0073

11. Parhizkar B., Obeidy W. K., Chowdhury S. A., Mohana Gebril Z., Ngan M. N. A. and Habibi Lashkari A. (2012) Android mobile augmented reality application based on different learning theories for primary school children, 2012 International Conference on Multimedia Computing and Systems, Tangiers, Morocco, 2012, pp. 404-408, doi: 10.1109/ICMCS.2012.6320114

12. Salvador-Herranz G., Pérez-López D., Ortega M., Soto E., Alcañiz M. and Contero M. (2013) Manipulating Virtual Objects with Your Hands: A Case Study on Applying Desktop Augmented Reality at the Primary School, 2013 46th Hawaii International Conference on System Sciences, Wailea, HI, USA, 2013, pp. 31-39, doi: 10.1109/HICSS.2013.390

\section{References:}

1. Bazovyj komponent doshkiljnoji osvity v Ukrajini (Derzhavnyj standart doshkiljnoji osvity) [Basic component of preschool education in Ukraine (State standard of preschool education)] nova redakcija (2021). Nakaz MON № 33 vid 12.01.2021 roku. URL: https://osvita.ua/legislation/doshkilna-osvita/79142/

2. Dopovnena, virtualjna ta inshi realjnosti [Augmented, virtual and other realities]. URL: https://www.it.ua/knowledge-base/technology-innovation/dopolnennaja-virtualnaja-i-prochie-realnosti

3. Modlo Je., Jechkalo Ju., Semerikov S., Tkachuk V. (2018) Vykorystannja tekhnologhiji dopovnenoji realjnosti u mobiljno orijentovanomu seredovyshhi navchannja VNZ [The use of augmented reality technology in a mobile-oriented university environment]. Naukovi zapysky. Serija: Problemy metodyky fizyko-matematychnoji i tekhnologhichnoji osvity, vol. 11(I). URL: https://arxiv.org/pdf/1807.10659

4. Tkachuk V., Semerikov S., Jechkalo Ju., Modlo Je. (2017) Tekhnologhija dopovnenoji realjnosti u mobiljnomu navchaljnomu seredovyshhi VNZ [Augmented reality technology in the mobile learning environment of universities]. URL:http://ds.knu.edu.ua/jspui/bitstream/123456789/791/1/Tkachuk_Semerikov_ Echkalo_Modlo.pdf

5. Billinghurst, M. (2002) Augmented Reality in Education. Seattle WA: New Horizons for Learning - Technology in Education.

6. Bondarenko O.V., Pakhomova O.V., Lewoniewski W. (2020) The didactic potential of virtual information educational environment as a tool of geog- 
raphy students training. In: Kiv A.E., Shyshkina M.P. (eds.) Proceedings of the 2nd International Workshop on Augmented Reality in Education (AREdu 2019), Kryvyi Rih, Ukraine, March 22, 2019. CEUR Workshop Proceedings 2547, 13-23. URL: http://ceur-ws.org/Vol 2547/ paper01.pdf (accessed 10 Feb 2020).

7. Dutta Kamalika (2015) Augmented Reality for E-Learning. URL: https://www.researchgate.net/publication/304078112_Augmented_Reality_ for_E-Learning - Title from the screen

8. Mehmet Kesim and Yasin Ozarslan (2012) Augmented reality in education: current technologies and the potential for education / Procedia - Social and Behavioral Sciences 47, 297-302. URL: https://cyberleninka.org/article/n/1234005.pdf

9. Morze Nataliia, Vember Viktoriia, Boiko Mariia, Varchenko-Trotsenko Liliia (2020) Organization of steam lessons in the innovative classroom. Open educational e-environment of modern University, no. 8. DOI: https://doi.org/ 10.28925/2414-0325.2020.8.9

10. Nezhyva Liudmyla, Palamar Svitlana, Lytvyn Oksan (2020) Perspectives on the use of augmented reality within the linguistic and literary field of primary education. Proceedings of the 3rd International Workshop on Augmented Reality in Education (2731), pp. 297-311. ISSN 1613-0073

11. Parhizkar B., Obeidy W. K., Chowdhury S. A., Mohana Gebril Z., Ngan M. N. A. and Habibi Lashkari A. (2012) Android mobile augmented reality application based on different learning theories for primary school children, 2012. International Conference on Multimedia Computing and Systems, Tangiers, Morocco, 2012, pp. 404-408, doi: 10.1109/ICMCS.2012.6320114

12. Salvador-Herranz G., Pérez-López D., Ortega M., Soto E., Alcañiz M. and Contero M. (2013) Manipulating Virtual Objects with Your Hands: A Case Study on Applying Desktop Augmented Reality at the Primary School, 2013 46th Hawaii International Conference on System Sciences, Wailea, HI, USA, pp. 31-39, doi: 10.1109/HICSS.2013.390 